Volume 6

Number 1 Spring 2015

Article 3

6-26-2015

\title{
Ruling the Market: How Venice Dominated the Early Music Printing World
}

Elizabeth M. Poore

Cedarville University, epoore@cedarville.edu

Follow this and additional works at: https://digitalcommons.cedarville.edu/musicalofferings

Part of the Ethnomusicology Commons, Fine Arts Commons, Musicology Commons, Music Performance Commons, and the Music Theory Commons

DigitalCommons@Cedarville provides a publication platform for fully open access journals, which means that all articles are available on the Internet to all users immediately upon publication. However, the opinions and sentiments expressed by the authors of articles published in our journals do not necessarily indicate the endorsement or reflect the views of DigitalCommons@Cedarville, the Centennial Library, or Cedarville University and its employees. The authors are solely responsible for the content of their work. Please address questions to dc@cedarville.edu.

\section{Recommended Citation}

Poore, Elizabeth M. (2015) "Ruling the Market: How Venice Dominated the Early Music Printing World," Musical Offerings: Vol. 6 : No. 1 , Article 3.

DOI: $10.15385 /$ jmo.2015.6.1.3

Available at: https://digitalcommons.cedarville.edu/musicalofferings/vol6/iss1/3 


\title{
Ruling the Market: How Venice Dominated the Early Music Printing World
}

\section{Document Type}

Article

\begin{abstract}
This paper attempts to prove that Venice was the main geographical center of music printing and publishing from the 1300 s to the late 1500 s using several economic, legal, and cultural factors. The primary research method was examining secondary sources on music printing, publishing, and European and Venetian history.
\end{abstract}

From the 1300 s to the late 1500 s, Venetian commercial trade and activity, including book publishing, reached unheard of levels. Venice held a powerful position in the European economy and its merchants were able to leverage this to great advantage when the new technology of printing became available. The specialized business of music printing and publishing was dominated by Venetian companies, who produced more sheet music than the rest of Europe combined between 1530 and 1560. The economic success of Venice also created a legal framework that benefited the burgeoning music printing industry. The printing and publishing of music required considerable capital such as specialized type faces, but the government system and capitalist economy of Venice made it easier for entrepreneurs to finance music publishing enterprises. The Venetian government system also encouraged close personal or even family relationships between different printing and publishing companies. This created a culture in which competing companies frequently benefited from cooperation. This paper makes it clear that there were a variety of economic, legal, and cultural factors that helped to propel Venice to its preeminent position as the provider of printed music to Europe during the 1300 s to the late $1500 \mathrm{~s}$. In the mid-Renaissance, when it came to printed music, Venice did indeed own the market.

\section{Keywords}

Music, music printing, music publishing, Venice, Italy, Renaissance, printing, single-impression printing, double-impression printing, Ottaviano Petrucci, Antonio Gardano, Girolamo Scotto

\section{Creative Commons License}

\section{cc) (i) $\Theta($}

This work is licensed under a Creative Commons Attribution-Noncommercial-No Derivative Works 4.0 License. 


\title{
Ruling the Market: How Venice Dominated the Early Music Printing World
}

\author{
Elizabeth M. Poore \\ Cedarville University
}

$\Upsilon$

he Most Serene Republic of Venice was the most prosperous place in Europe from the 1300s to the late 1500s. ${ }^{1}$ This period, commonly known as the Renaissance, saw the arrival of printing from Asia and the rise of Venice as the primary center for printing and publishing in Europe. Venetian commercial and industrial strength and activity, including the book trade, reached unheard of levels. Venice held a powerful position in the European economy and its merchants were able to leverage this to great advantage when the new technology of printing became available. The specialized business of music printing and publishing was dominated by Venetian companies, who produced more sheet music than the rest of Europe combined between 1530 and $1560 .^{2}$ The printing and publishing of music required considerable capital, but the government system and capitalist economy of Venice made it easier for entrepreneurs to finance music printing ventures. The Venetian legal system encouraged close personal or even family relationships between different printing and publishing companies, creating a culture in which competing companies frequently benefited by being able to cooperate as well. These economic, legal, and cultural factors helped to propel Venice to its preeminent position as the provider of printed music to the growing upper and middle classes of Europe during this period.

With an empire based on trade rather than conquest, Venice was described as the marketplace of the world. ${ }^{3}$ Strategically positioned as a

\footnotetext{
${ }^{1}$ Bill Gilbert, Renaissance and Reformation (Lawrence, KS: Carrie Books, 2003), chap. 3. http://vlib.iue.it/carrie/texts/carrie books/gilbert/03.html.

${ }^{2}$ Jane Bernstein, Print Culture and Music in Sixteenth-Century Venice (New York: Oxford University Press, 2001), 22.

${ }^{3}$ Ibid., 9.
}

Musical Offerings, vol. 6, no. 1, pp. 49-60. ISSN 2330-8206 (print); ISSN 2167-3799 (online);

(C) 2015, Elizabeth Poore, licensed under CC BY-NC-ND (http://creativecommons.org/licenses/by-nc-nd/3.0/) 
seaport on the trade route to the East, Venice had a large fleet of trading vessels that carried goods such as spices, silks, and glassware from Asia to Venice and distributed them around Europe. Many of the goods that traveled through Venice, or were manufactured there, were expensive luxury items with high profit margins, generating large incomes for Venetian merchants. This pre-existing, fast, and reliable distribution network made it comparatively easy and inexpensive for Venetian music publishers to sell their publications throughout Europe, thus giving the publishers a larger market and lower costs than their competitors in other cities. ${ }^{4}$ As the economic superpower of Europe during the Renaissance, Venice was able to define the terms of trade, including receiving payment in its own currency, the gold Ducat, which was used for financial transactions all over Europe as late as the seventeenth century. ${ }^{5}$ Through trade, Venice had become rich and influential and it had a substantial population of wealthy merchants. These citizens frequently saw an interest in the arts as a sign of sophistication, and had both time and money to devote to music and other artistic pursuits. This combination of economic success and culture-seeking residents provided an ideal place for the music printing and publishing industry to thrive.

The volume of commerce and trade also meant that Venice had highly developed financial and legal systems that benefitted music printing. This led to the availability of money to finance risky ventures such as music printing and publishing. The relative newness of printed music and the lack of established volume markets made printed music an uncertain business, especially during the late 1400s. In addition, the specialized skills, expensive equipment, and complex processes required to print music meant that significant capital was needed to finance the printing and publishing of a musical work. The existence of a clear and consistent legal framework to govern finance and trade meant that investors were willing to use their assets for speculative ventures, knowing that they would not be cheated of their share of the rewards for a successful outcome. In addition, the investors also knew that their losses would be limited in the event that the music did not sell as hoped.

\footnotetext{
${ }^{4}$ Ibid., 10.

${ }^{5}$ Richard J. Agee, The Gardano Music Printing Firms 1569-1611 (Rochester, NY: University of Rochester Press, 1998), 13.
} 
These factors led to Venice becoming a magnet for the skilled artisans who were necessary for the specialized business of music printing. In the late-fifteenth and early-sixteenth centuries, music was printed using the double-impression process, where the same page was printed two or three times, requiring great skill in composition and printing to align the different impressions correctly to form the whole page. This complex process required skills unique to music printing and made the production costs of sheet music significantly higher than for most books. Usually the staves would be printed first, with the notes, words, and other symbols overlaid afterward. There were many different variations on this system, some of which included hand-drawn notes or staves. In some cases, music would be printed with blank staves so that the notes could be drawn by hand using whichever musical notation was in use where the music was eventually sold. The doubleimpression process was used in Venice by Ottaviano Petrucci in 1501 when he produced the first book of polyphonic music set from movable type. This book was notable at the time for the small size of its type, the intricacy of the white mensural notation, and the precision with which the multiple impressions were aligned. ${ }^{6}$

The Venetians did not just rely on their strategic advantages, but competed by producing better quality products than their compatriots across Europe. The quality of Venetian sheet music was helped by an influx of skilled workers. Specialized workers designed the typefaces, manufactured the type, and set the plates used for printing both the words and music. They found a ready market for their skills in Venice, and their migration was part of a "virtuous circle" where the demand for music attracted the skills required to fulfill that demand, which in turn increased the demand, leading to still greater demand for the skilled workers. The fact that all of these workers came to Venice deprived other cities of their services and helped to cement the dominance of the Venetians in the music printing and publishing trade.

The technological key to making music printing truly profitable was the invention of the single-impression process, which enabled sheet music to be produced by printing each page just once. This process was first used in 1519 by John Rastell in London, although it was not until 1528 when Pierre Attaingnant, working in Paris, took full commercial

${ }^{6}$ Bernstein, Print Culture, 20. 
advantage. $^{7}$ By 1538 , the technique had spread through Europe and reached Venice. This innovation dramatically changed the music printing industry in Venice, enabling new works to be printed quicker, cheaper, and at higher volumes. Printers such as Antonio Gardano and Girolamo Scotto were able to leverage single-impression printing to such great effect that over the next thirty years, they produced more than 850 music publications, a total which exceeded the combined output of all other music printers in Europe. ${ }^{8}$ The acceleration enabled by single-impression printing can be seen from the fact that by the end of the 1540s, the Scotto firm was publishing as many as twenty musical works each year, about four times the total output of Venetian music printers from the previous decade. ${ }^{9}$ The extensive distribution network available to the Venetian music manufacturers meant that they were quickly able to increase their print volumes, lowering the cost of each copy and raising their profits. The new method of printing was available throughout Europe, but the technology alone was not enough to allow other cities to challenge the supremacy of Venice. The other business, legal, and cultural factors discussed in this paper enabled the Venetians to quickly adopt the new invention, use it to reduce costs, capture new markets, and thus enhance the profitability and dominance of their music printing businesses.

The Venetian legal system assisted the burgeoning music printing industry with its system of granting "privileges" or limited monopolies through the Venetian Senate. The granting of monopolies by the ruler was common practice in many countries at the time, but the Venetian form of government meant that monopolies were implemented in a fair and open way that encouraged risk-taking and innovation. The first person to set up a printing press in Venice, Johannes de Spira, was granted a five-year privilege on printing in 1469. However, he died only a few months later so the privilege lapsed. ${ }^{10}$ The first monopoly on music printing was granted to Ottaviano Petrucci in 1498, giving him the rights to music for organ and lute for twenty years. ${ }^{11}$ In 1514 , following war with the League of Cambrai, Petrucci petitioned the Venetian Senate for a renewal of his monopoly. He claimed that he had

\footnotetext{
${ }^{7}$ Jane A. Bernstein, Music Printing in Renaissance Venice: The Scotto Press 1539-1572 (Oxford: Oxford University Press, 1998), 27.

${ }^{8}$ Bernstein, Print Culture, 22.

${ }^{9}$ Bernstein, Music Printing in Renaissance Venice, 161.

${ }^{10}$ Bernstein, Print Culture, 10.

${ }^{11}$ Stanley Boorman, Ottaviano Petrucci: Catalogue Raisonné (New York: Oxford University Press, 2006), 77-78.
} 
been unable to take full advantage of the privilege up to that point because trade had been decreased by the war. The Senate renewed his privilege for a period of five years. ${ }^{12}$ However, it did not take the Venetians long to realize that blanket monopolies of this kind were counter-productive and would reduce the volume of trade in the music industry. A decree issued in 1517 revoked all existing privileges, outlawed privileges covering wide ranges of musical works, and introduced a "novelty" requirement that a protected work could not have been printed earlier. ${ }^{13}$

By the 1530s, privileges were being granted for the printing and publishing of individual works of music. A minimum print run of 400 copies was required to qualify for a privilege and it is estimated that an average print run for a musical work at the time was around 500 copies. ${ }^{14}$ Day-to-day government in Venice was by a 120 -member Senate, and the granting of privileges required a large majority, sometimes as large as five-sixths, to vote in favor of the privilege. ${ }^{15}$ Compared to other European cities where the granting of monopoly licenses was often subject to the whims of a single king, prince, or duke, the Venetian system was much less liable to abuse or corruption. The targeted use of monopoly gave music printers and publishers time to recoup the investment required to print and publish new works. The limiting of the privilege to five or ten years (occasionally even as little as one year) enabled others to compete in publishing popular works and thus tended to reduce prices. ${ }^{16}$ Since the scope of a monopoly was defined as a single musical work, many different companies could still participate and compete in the growing market for printed music. The structure of the Venetian government and legal system meant that printers and publishers could not rely on the patronage of a monarch or the church. This forced the Venetian music printing industry to be from the beginning a capitalistic enterprise, dependent on innovation and sensitive to market forces for success.

\footnotetext{
${ }^{12}$ Bernstein, Print Culture, 75.

${ }^{13}$ Ronan Deazley, Martin Kretschmer, and Lionel Bently, eds., Privilege and Property Essays on the History of Copyright (Cambridge, United Kingdom: OpenBook, 2010), 146.

${ }^{14}$ Bernstein, Print Culture, 11.

${ }^{15}$ Eric Dursteler, ed., A Companion to Venetian History, 1497-1700 (Leiden, The Netherlands: Koninklijke Brill NV, 2013), 57.

${ }^{16}$ Deazley, ed, Privilege and Property, 145-146.
} 
Through trial and error, printing and publishing companies also learned to regulate themselves. In 1473, the infant printing industry in Venice crashed due to an over-supply of Latin translations of classical Greek texts. Too many printers were producing the same works and many companies went bankrupt because supply outweighed demand. This episode taught some important lessons which arguably set the scene for much of the success of the Venetian book businesses up to the end of the sixteenth century. First, the industry discovered the need to produce a greater variety of publications in different subject areas and genres. Second, firms that wanted to avoid direct competition needed to find their own specialized niches in which to work as part of a more diversified industry. This did not entirely insulate companies from competition, but it frequently only happened when multiple printers were printing copies of already successful works. ${ }^{17}$ For this specialization to be successful, companies needed to be able to trust each other and know that their competitors would respect their market segment.

There were three main roles for firms to fulfill within the sheet music industry: printer, publisher, and bookseller. The printer would control the type setting with the publisher taking financial responsibility for publication and distribution, and the bookshop selling the music. Most companies specialized in one area, but would sometimes perform two of these roles. Larger companies such as the Scotto firm frequently acted in all three capacities. ${ }^{18}$ For example, a printing company might do most of its business by printing on commission, receiving a fixed fee for their services. This would provide the company with a steady income. The firm would be guaranteed payment, but because they had not taken any financial risks, they would not gain any extra profit if the book sold well. On occasion, a printer might also finance the publishing of a work, either alone or in collaboration with other companies and individuals. The formation of different syndicates to finance the printing and publishing of different works was a way of sharing, and hence limiting, the risks involved so that no one company had to risk its business to finance a new work. The high concentration of music printers and publishers in Venice provided unique opportunities for these kinds of partnerships.

\footnotetext{
${ }^{17}$ Bernstein, Print Culture, 16-17.

${ }^{18}$ Ibid., 12.
} 
The specialization that happened after the crash of 1473 also encouraged collaboration between different companies. If a large publishing house acquired the rights to a piece of music and wanted to publish the work, the firm would need to find a printer who specialized in printing music. Thus, the publishing houses grew accustomed to working with many different printers, and printers worked with many publishers. Specialization also led to companies developing a high degree of expertise in a narrow area, and an accompanying improvement in the quality of the printed product. Along with the connections enabled by their international trade network, this brought Venetian printing and publishing companies to dominance in numerous subject areas including music. ${ }^{19}$

The two largest music-publishing houses, Scotto and Gardano, provide examples of cooperative marketing strategies used in Venice in the sixteenth century. Although they were long thought to be cutthroat competitors and Scotto was frequently accused of not respecting his main competitor's privileges, newer evidence suggests that the two companies actually worked together very closely and coordinated their activities. ${ }^{20}$ They developed their own distinct clientele and were careful to source music from geographically separate areas and in some cases different genres to avoid direct competition. The two companies began to reprint each other's publications as well as their own. ${ }^{21}$ Successful works of music were frequently republished, often with minor changes to the format or to the other works included in the same book so that it could be marketed as "new." This is a tactic that has remained successful even today.

Family connections and personal relationships also became important in an ecosystem of specialized companies and workers. Venetian law stated that all of the male heirs shared jointly in the estate when the head of the family died. This gave incentives for those family members to form partnerships in order to have their businesses continue and flourish. Almost all of the leading publishers in Venice were examples of such fraterne. ${ }^{22}$ With such a close connection between family and business, it is not surprising that strategic marriages were used to strengthen the connections between companies. If a widow inherited a publishing firm, it was not uncommon for her to remarry a bookman in

\footnotetext{
${ }^{19}$ Ibid., 17.

${ }^{20}$ Bernstein, Music Printing in Renaissance Venice, 157.

${ }^{21}$ Ibid., 160.

${ }^{22}$ Bernstein, Print Culture, 13.
} 
order to further the interests of the press. Paola da Messina presents an interesting case because she married four times, each to a different music printer to bolster business alliances. In addition, aspiring young printers would often seek marriages to daughters of successful printers or publishers. For instance, the music printer Antonio Gardano married the daughter of Venetian printer Agostino Bindoni. Jane Bernstein speculates that Bindoni could have forgone the typical cash gift for a dowry, and instead given material goods such as books, presses, type, and paper. The dowry could also have included the invisible assets of business connections and clients that would boost the audience of Gardano's works. ${ }^{23}$ It is clear that the existence of personal connections was an important cultural factor in enabling different companies to build strong alliances, avoid head-on competition, and cooperate in many different ways.

One of the most influential Venetian music printing and publishing families was the Scotto family. Ottaviano Scotto arrived in Venice before 1479. Initially, he published books in Latin, but he played a formative role in the development of sheet music, producing his first musical work in 1482 when he became the first Italian to print music with moveable type. ${ }^{24}$ When Ottaviano died in 1498 , the firm passed to his nephews since he had no sons. Shortly after his death the Scotto firm was one of the few to emerge more or less unscathed from one of the worst financial crises in the history of the republic. It may be that this experience encouraged the Scotto family to seek partners for their publishing ventures. A manuscript surviving from 1507 shows Amadio Scotto entering into a partnership with five other bookmen to finance books. ${ }^{25}$ From 1513, the title pages of musical works published under the Scotto name contain the words "ac Sociorum" showing that they were also funded by others. ${ }^{26}$ Amadio Scotto is also known for acting as Petrucci's financial partner by underwriting Petrucci's original venture in music printing that resulted in the first printed polyphonic music from movable type. ${ }^{27}$ There are numerous other examples of the Scotto family collaborating with other companies, even with their most prolific rival Antonio Gardano. In fact, it has been stated that

\footnotetext{
${ }^{23}$ Ibid., 13-14.

${ }^{24}$ Bernstein, Music Printing in Renaissance Venice, 32-33.

25 Ibid., 36.

${ }^{26}$ Ibid.

${ }^{27}$ Bernstein, Print Culture, 120.
} 
practically every printer and publisher in the Italian peninsula worked with the Scotto family at some time. ${ }^{28}$

It could be said that the House of Scotto acted as an organizing force that divided up work and profits among a group of loosely cooperating companies, while making sure that it retained the leadership position. Today, this collaboration would be considered a significant breach of antitrust legislation, but it arguably contributed to the successful development of music publishing and printing in Venice. Benefiting from the introduction of single-impression printing, Girolamo issued over 400 music editions from 1539 to 1572 , just over half of the total works published by the company in that period..$^{29}$ Girolamo Scotto's output of music was surpassed only by Antonio Gardano, who, unlike Scotto, only printed music. The House of Scotto was undoubtedly one of the most influential music publishers in the whole of Europe during this period.

The Scotto firm provides a good example of the overlapping of family and commercial interests. Girolamo Scotto operated the press by himself, but he co-owned the company with his brother, Ottaviano II. Several of Girolamo's nephews are known to have worked for him in cities such as Naples, Rome, Milan, and Mantua. Other relatives, including his nephew Melchiorre, who eventually inherited the business, were employed in Venice. Having trusted family members in positions of influence both inside and outside of Venice helped make the business of distributing books and receiving timely and accurate payment for them much more routine. Since the Scotto company was one of the largest, it provided employment to a large number of extended family members, but other smaller firms followed the same business structure.

Cooperation between different companies took many forms, not just financial partnerships. Firms would often share typographical supplies and equipment. Jane Bernstein speculates that Scotto either sold or rented a particular set of music typefaces known as "Music Font 1" to several different Roman and Venetian printers. The elegant font can be seen consistently in Scotto's work over a twenty-year period, but it can also be observed periodically in several other printers' work, indicating

${ }^{28}$ Bernstein, Music Printing in Renaissance Venice, 118.

${ }^{29}$ Bernstein, Print Culture, 125. 
that they also had access to the same type. ${ }^{30}$ It would have been financially unwise for several different companies to make the capital investment required to each purchase their own musical matrices. Since Scotto would have been the largest company, with greater resources, a more economically viable solution would have been for Scotto to own the music font and rent or sell it to his competitors. This type of "in kind" partnership would have been assisted by the network of family connections between many of the companies involved.

The evidence that Venice was the main center for music publishing and printing during the Renaissance is undeniable. The fact that the combined output of the two main printing houses in Venice exceeded the production of all other music printers in Europe is remarkable. There are multiple economic reasons for the preeminence of Venice including the powerful position that Venice held in the European economy which created the advantages of an extensive, fast, and reliable distribution network. Venice used its dominance to define the terms of trade including the use of its own currency for receiving payments. These economic factors were clearly a big advantage to the fledgling Venetian printing industry. The economic success of Venice also created a legal framework that benefited the industry. Commercial law became well developed in Venice, producing an environment which ensured fair rewards for investments in risky ventures such as music printing and publishing. Combined with the judicious use of the privilege system, these legal factors made Venice a place where capital was more easily available to finance the publishing of music. In addition, the cultural environment in Venice helped to make the music publishing industry successful. The way that the printing industry as a whole organized itself to segment the market and avoid excessive competition helped in this success. The Venetian law of inheritance encouraged the intermarriages of the families Venetian printers. The resulting close ties between companies that might otherwise have been bitter competitors were a cultural factor that undoubtedly helped the industry to manage itself. The same ties also made it easier to form cooperative partnerships to fund publishing projects. It is clear that there were a variety of economic, legal, and cultural factors that together promoted the success of Venice as a center for music printing and publishing. In the sixteenth century, when it came to printed music, Venice did indeed own the market.

${ }^{30}$ Bernstein, Music Printing in Renaissance Venice, 94-95. 


\section{Bibliography}

Agee, Richard J. The Gardano Music Printing Firms, 1569-1611.

Rochester, NY: University of Rochester Press, 1998.

Bernstein, Jane A. Print Culture and Music in Sixteenth-Century

Venice. New York: Oxford University Press, 2001.

. Music Printing in Renaissance Venice: The Scotto Press 15391572. Oxford: Oxford University Press, 1998.

Boorman, Stanley. Ottaviano Petrucci: Catalogue Raisonné. New York: Oxford University Press, 2006.

. Studies in the Printing, Publishing and Performance of the Sixteenth Century. Aldershot, Hampshire, Great Britain: Ashgate, 2005.

Buja, Maureen. "Antonio Barré and Music Printing in Mid-Sixteenth Century Rome.” PhD diss., University of North Carolina, 1996.

Carter, Tim. Music, Patronage, and Printing in Late Renaissance Florence. Aldershot, Hampshire, Great Britain: Ashgate, 2000.

Cusick, Suzanne. Valerio Dorico: Music Printer in Sixteenth-Century Rome. Ann Arbor, MI: UMI Research Press, 1981.

Deazley, Ronan, Martin Kretschmer, and Lionel Bently, eds. Privilege and Property: Essays on the History of Copyright. Cambridge, UK: OpenBook, 2010.

Duggan, Mary Kay. Italian Music Incunabula: Printers and Type. Berkeley: University of California Press, 1992.

Dursteler, Eric, ed. A Companion to Venetian History, 1497-1700. Brill's Companions to European History, vol. 4. Leiden, The Netherlands: Koninklijke Brill NV, 2013.

Gamble, William. Music Engraving and Printing: Historical and Technical Treatise. New York: Arno Press, 1979. 
Gilbert, Bill. Renaissance and Reformation. Lawrence, KS: Carrie Books, 2003. http://vlib.iue.it/carrie/texts/carrie books/gilbert/03.html.

A Guide to the Exhibition in the King's Library: Illustrating the History of Printing, Music-printing, and Bookbinding. London: British Museum, 1939. Exhibition catalog.

Jackson, Susan. "Berg and Neuber: Music Printers in SixteenthCentury Nuremberg." PhD diss., City University of New York, 1998.

Judd, Cristle Collins. Reading Renaissance Music Theory: Hearing with the Eyes. Cambridge, UK: Cambridge University Press, 2000.

Kreider, J. Evan. The Printing of Music, 1480-1680. Vancouver: Alcuin Society, 1980.

Krummel, Donald William, and Stanley Sadie, eds. Music Printing and Publishing. New York: W.W. Norton, 1990.

Lewis, Mary S. Sources and the Circulation of Renaissance Music. Farnham: Ashgate, UK, 2012.

Ongania, Ferdinando. Early Venetian Printing Illustrated. Venice, 1895.

The Printed Note: 500 Years of Music Printing and Engraving. Toledo, OH: Toledo Museum of Art, 1957. Exhibition catalog.

Steele, Robert. The Earliest English Music Printing: A Description and Bibliography of English Printed Music to the Close of the Sixteenth Century. London: Chiswick Press, 1903.

Van Orden, Kate, ed. Music and the Cultures of Print. New York: Garland, 2000. , ed. Music, Authorship, and the Book in the First Century of Print. Berkeley: University of California Press, 2014. 